Diabetologia 4, 249-252 (1968)

\title{
ORIGINALS
}

\section{Glucose Metabolism of Isolated Mammalian Islets of Langerhans; Effects of Glucagon, 2-Deoxy-D-Glucose and D-Mannoheptulose*}

\author{
R.J. JARRETT and H. KEEN
}

Department of Medicine, Guy's Hospital, London, S.E. 1

Received: January 31, 1968

Summary. The hypothesis that glucagon effects insulin release by causing glycogenolysis within the $B$ cells of the Islets of Langerhans was tested in two ways. In the first, islets were incubated in the presence of ${ }^{14} \mathrm{C}$-glucose and with or without glucagon, and the ${ }^{14} \mathrm{CO}$ production measured. Glucagon failed to elicit a fall in ${ }^{14} \mathrm{CO}_{2}$ production, suggesting little dilution of the intra-cellular glucose-6phosphate pool. In the second, the effect of glucagon was studied on islet glycogen, previously labelled with radioactive glucose. Glycogen radioactivity following chemical isolation was similar when glucagon was absent or present. No effect of 2-deoxy-D-glucose on ${ }^{14} \mathrm{CO}_{2}$ production from labelled glucose was found but it was greatly diminished in the presence of D-mannoheptulose.

Métabolisme du glucose des îlots de Langerhans isolés de mammifères; effets du glucagon, du 2-deoxy-D-glucose et du D-mannoheptulose

Résumé. Nous avons examiné de deux façons l'hypothèse que l'action du glucagon sur la libération de l'insuline est attribuée à la glycogénolyse dans les cellules bêta des îlots de Langerhans. - En premier lieu, les îlots furent incubés en présence de ${ }^{14} \mathrm{C}$-glucose avec ou sans glucagon, et la production de ${ }^{14} \mathrm{CO}_{2}$ fut mesurée. La présence du glucagon ne produisit aucune réduction dans la production de ${ }^{11} \mathrm{CO}_{2}$, ce qui suggère done qu'il n'y a pas eu de dilution du "pool" glucose-6-phosphate intracellulaire. - En second lieu, nous avons examiné l'effet du glucagon sur le glycogène des îlots, marqué préalablement au glucose radio-actif. Après l'isolement chimique du glycogène, sa radioactivité fut la même avec ou sans glucagon. Le 2-deoxy-D-glucose n'eut aucun effet sur la production de ${ }^{14} \mathrm{CO}_{2}$ à partir du glucose marqué mais cette production fut fortement diminuée par la présence de D-mannoheptulose.

Glucosestoffwechsel isolierter Langerhans'schen Inselzellen von Säugetieren; Einwirkung von Glucagon, 2-desoxy$D$-Glucose und D-Mannoheptulose

Zusammenfassung. Die Hypothese, daß Glucagon über eine gesteigerte Glykogenolyse in den $\beta$-Zellen der Langerhans'schen Inseln auf die Insulinabgabe wirkt, wurde mit zwei verschiedenen Verfahren überprüft. Erstens wurden die Langerhans'schen Inseln in Gegenwart von ${ }^{14} \mathrm{C}-\mathrm{Glu}$ cose mit und ohne Glucagon inkubiert und die ${ }^{14} \mathrm{CO}_{2}$ Produktion gemessen. Glucagon senkte die ${ }^{14} \mathrm{CO}_{2}$ Bildung nicht, so daß anzunehmen ist, daß nur eine geringe Verdünnung des intracellulären Glucose-6-Phosphat-Pool eintritt. - Zweitens wurde der $\operatorname{EinfluB}$ von Glucagon auf das mit radioaktiver Glucose markierte Inselzell-Glykogen untersucht. Dieses Glykogen zeigte nach seiner chemischen Isolierung nach Inkubation mit und ohne Glucagon die gleiche Radioaktivität. Zusatz äquimolecularer Mengen von 2-Desoxy-D-Glucose beeinfluBte die ${ }^{14} \mathrm{CO}_{2}$ Bildung aus markierter Glucose nicht, diese war jedoch in Gegenwart von D-Mannoheptulose stark herabgesetzt.

Key-words: Glucagon, islets of Langerhans, glycogen, glucose.
Glucagon has been shown to raise serum insulin levels in vivo (Samols, Marri and Marks, 1965; Karam, Grasso, Weginnka, Grodsky and Forsham, $1966)$ and to stimulate insulin release in vitro ( $R_{-C A N}$ dera, R-Candela, Martin Hernandez and CastuLLa-Cortazar, 1963; TURner and MoIntyre, 1966; DevrIM and ReCANT, 1966; Grodsky and BenNeTT, 1966). In the liver cell, glucagon causes glycogenolysis by stimulating the adenyl-cyclase system to produce cyclic $3^{\prime}, 5^{\prime}$-A.M.P., which activates phosphorylase (SUTHERLAND and RALL, 1960). A similar chain of events may occur in the $B$ cell, the rise in intra $B$ cell glucose-6-phosphate concentration acting as the trigger to insulin release. Evidence of a role of cyclic $3^{\prime}, 5^{\prime}$ A.M.P. has recently been reported (TuRTLE and KIP-

* This study was supported by a grant to R.J.J. from the Medical Research Council of Great Britain. Counting equipment was generously provided by Grant No. AM 6135 MET from the U.S. Public Health Service.
NIS, 1967). We have attempted to test this hypothesis by studying the effects of glucagon and other substances upon metabolism of ${ }^{14} \mathrm{C}$-glucose in isolated islets of Langerhans micro-dissected from the rat pancreas.

\section{Materials and Methods}

U-14 $\mathrm{C}-\mathrm{D}$-glucose (specific activity $97.4 \mathrm{mc} / \mathrm{mM}$ ) was obtained from the Radiochemical Centre, Amersham. D-glucose (Analar grade) was obtained from British Drug Houses; 2-deoxy-D-glucose and oyster glycogen (Type 11) from Sigma Chemical Company. D-mannoheptulose, prepared by Professor E. Srmon, was kindly given by $\mathrm{Mr}$. D. Turner and crystalline glucagon (Lot No. 258-234 B-167-1) by Dr. Mary Root of Lilly Laboratories.

The islets were obtained from fed animals as previously described (KEEN, SELIS and JARRETT, 1965; 
JARRETT and KEEN, 1966). The basic incubation medium was Krebs-Ringer bicarbonate buffer (UmBreIr, BURRIS and STAUFFER, 1964) containing $2 \mathrm{mg} / \mathrm{ml}$ crystalline bovine albumin (Armour). To this, radioactive (and, when necessary, unlabelled) glucose was added. The substance under study was added to a portion of this medium and the remainder used for the control incubation. For experiments involving the collection of ${ }^{14} \mathrm{CO}_{2}$, the islets were incubated in small glass centre wells in $0.15 \mathrm{ml}$ medium, in a shaking water bath at $37^{\circ} \mathrm{C}$. The gas phase was $95 \% \mathrm{O}_{2}: 5 \% \mathrm{CO}_{2}$. At the end of the incubation, metabolism was stopped and $\mathrm{CO}_{2}$ discharged from the medium by the injection of $0.2 \mathrm{ml}$. N.HCl into the centre well. The liberated $\mathrm{CO}_{2}$ was collected overnight in $1.0 \mathrm{ml}$ saturated $\mathrm{Ba}(\mathrm{OH})_{2}$, which was injected into the base of the container vial. The $\mathrm{BaCO}_{3}$ precipitate was washed twice with $10 \mathrm{ml}$ $0.1 \mathrm{~N} \mathrm{NaOH}$ to remove soluble radioactive contaminants. The $\mathrm{CO}_{2}$ was then discharged from the $\mathrm{Ba}$ $\mathrm{CO}_{3}$ with $\mathrm{N} \mathrm{HCl}$ and re-collected in $0.5 \mathrm{ml}$ phenylethylamine solution (WOELLER, 1961), which was finally added to $8.0 \mathrm{ml}$ phosphor (PPO $0.4 \%$ and Popop $0.01 \%$ in toluene) and counted in a Packard liquid scintillation spectrometer. Three flasks, containing medium, without islets, were carried through the whole procedure to provide an estimate of 'background' and non-specific radioactivity carried over. Estimations on experimental and control media were made in triplicate by incubating three batches of micro-dissected islets in each. Each flask contained equal numbers of islets (about 15) taken from the same pancreas. To ensure a balanced distribution, the islets were pooled (in buffer at $4^{\circ} \mathrm{C}$ ) before transfer to the incubation vials; islets of similar size were then distributed among the vials.

\section{Glycogen labelling}

In these experiments, requiring the prior incorporation of radioactive glucose into islet glycogen, all the micro-dissected islets were first incubated together in $0.25 \mathrm{ml}$ medium, containing $50-75 \mu \mathrm{C}$ U.14C-glucose, for two hours. The islets were then washed in fresh, chilled buffer and transferred to centre wells, into medium containing unlabelled glucose, with or without glucagon. After a specified period of incubation at $37^{\circ} \mathrm{C}$, the batches of islets were removed, transferred to $2 \mathrm{ml}$ $30 \% \mathrm{KOH}$ and homogenised along with $5 \mathrm{mg}$ carrier glycogen. The homogenate was placed in a boiling water bath for $1 \mathrm{~h}$ and then centrifuged. The deposit was discarded, and glycogen precipitated from the supernatant with three volumes of absolute ethanol. The precipitated glycogen was isolated by centrifugation, re-dissolved in water and again precipated with ethanol, the whole process being repeated six times. The final precipitate was suspended in phosphor, using finely divided silica, and counted in the liquid scintillation spectrometer. The identity of the radioactivity in the final glycogen precipitate was confirmed by the demonstration that, after acid hydrolysis, the radioactivity had a mobility identical with that of labelled glucose on paper chromatography.

The test concentration of glucagon used through. out these experiments, $2.5 \mu \mathrm{g} / \mathrm{ml}$, was selected after consideration of the concentrations found by others to stimulate insulin release in vitro (TuRNkR and Mo Intyre, 1966; Devrim and ReCant, 1966).

\section{Results}

1. The effect of glucagon upon ${ }^{14} \mathrm{CO}_{2}$ production. If glucagon promotes glycogenolysis, then the resulting increase of glucose-6-phosphate within the B-cell should dilute the radioactivity of the labelled glucose6-phosphate generated from $\mathrm{U}^{14} \mathrm{C}$ glucose entering the cell from the incubation medium. Assuming that there is no major change in the rate of glucose oxidation, this dilution should lead to a fall in the yield of ${ }^{14} \mathrm{CO}_{2}$. Table 1 shows the results of several experiments in which islets were incubated with and without glucagon for various periods of time. In these experiments, only labelled glucose was present in the incubation medium. No significant diminution in ${ }^{14} \mathrm{CO}_{2}$ production occurred in the presence of glucagon.

Table 1. The effect of glucagon upon the production of ${ }^{14} \mathrm{CO}_{2}$ from $U \cdot{ }^{14} C$-glucose by isolated islets of Langerhans

\begin{tabular}{lllr}
\hline & $\begin{array}{l}\text { No. } \\
\text { of islets } \\
\text { per flask }\end{array}$ & $\begin{array}{l}\text { Incubation } \\
\text { Time (min) }\end{array}$ & $\begin{array}{l}\text { cpm }{ }^{14} \mathrm{CO}_{2} \\
\text { Mean } \pm \mathrm{S} . \mathrm{E} . \mathrm{M} .\end{array}$ \\
\hline 1. Glucagon & 15 & 90 & $3493 \pm 979$ \\
Control & 15 & & $3299 \pm 333$ \\
2. Glucagon & 13 & 60 & $853 \pm 17$ \\
Control & $\mathbf{1 3}$ & & $887 \pm 229$ \\
3. Glucagon & 14 & 60 & $1797 \pm \mathbf{1 3 3}$ \\
Control & 14 & & $1983 \pm 270$ \\
4. Glucagon & 16 & 60 & $5947 \pm 949$ \\
Control & 16 & & $6179 \pm 241$ \\
\hline
\end{tabular}

2. The effect of glucagon upon pre-labelled glycogen. A direct effect of glucagon on glycogenolysis was sought by prior labelling of glycogen with labelled glucose and then measurement of the radioactivity of the glycogen after subsequent exposure to glucagon. In these experiments the duration of the first (labelling) incubation with $\mathrm{U}^{14} \mathrm{C}$ glucose was always two hours, but that of the second (exposure) incubation was varied. No unlabelled glucose was present during the first incubation; the concentration of unlabelled glucose during the second incubation was $1.5 \mathrm{mg} / \mathrm{ml}$. Glucose was added at this stage in an attempt to slow "spontaneous" glycogenolysis. Preliminary experiments showed little difference in the radioactivity of glycogen in islets extracted immediately after the first incubation and those extracted after subsequent incubation in 
medium containing glucose at a concentration of 1.5 $\mathrm{mg} / \mathrm{ml}$. An example of such an experiment is shown in Table 2, which also shows the effect of the presence of glucagon on the glycogen radioactivity. It can be seen that there was no reduction in the total radioactivity of islet glycogen attributable to glucagon.

Table 2. The effect of glucagon upon recoverable ${ }^{14} \mathrm{C}$ radioactivity in glycogen extracted from islets after an initial incubation in the presence of $U-{ }^{14} C$-glucose

\begin{tabular}{llll}
\hline & $\begin{array}{l}\text { No. } \\
\text { of islets } \\
\text { per flask }\end{array}$ & $\begin{array}{l}\text { Duration of } \\
\text { second } \\
\text { incubation } \\
\text { (min) }\end{array}$ & $\begin{array}{l}\text { cpm for }{ }^{14} \mathrm{C} \\
\text { glucose } \\
\text { in glycogen }\end{array}$ \\
\hline 1. Glucagon & 15 & 60 & $350 \pm 54$ \\
Control & 15 & 60 & $489 \pm 91$ \\
2. Glucagon & 10 & 45 & $105 \pm 19$ \\
Control & 10 & 45 & $182 \pm 28$ \\
3. Glucagon & 17 & 30 & $\mathbf{1 5 2 1 \pm 1 0 9}$ \\
Control & 17 & 30 & $1534 \pm 61$ \\
4. Glucagon & 14 & 45 & $1122 \pm 114$ \\
Control (1) & 14 & 45 & $\mathbf{1 3 4 2 \pm 1 4 0}$ \\
Control (2) & 14 & Not incubated & $\mathbf{1 4 0 0 \pm 2 8 6}$ \\
\hline
\end{tabular}

3. The effects of 2-deoxy-D-glucose and of mannoheptulose on glucose oxidation. The relevance of these experiments is provided by the experiments of DEVRIM and ReCarT (1966) who claimed that 2-deoxy-D-glucose inhibited glucagon-stimulated insulin release from rat pancreas pieces in vitro. In the initial experiments (Table 3), islets were incubated with glucose alone or with glucose accompanied by an equimolar quantity of 2-deoxy-D-glucose, the glucose being equally labelled with $\mathrm{U}^{14} \mathrm{C}$ glucose in either situation. No effect of 2 deoxy-D-glucose on ${ }^{14} \mathrm{CO}_{2}$ production was observed. In further experiments, therefore, islets were pre-in-

Table 3. The effect of 2-deoxy-D-glucose upon the production of ${ }^{14} \mathrm{CO}_{2}$ from $U-{ }^{14} \mathrm{C}$-glucose by isolated islets

(i) In this experiment the U-14C glucose was added after pre-incubation lasting $60 \mathrm{~min}$. The further incubation lasted $120 \mathrm{~min}$.

(ii) In this experiment, the islets were taken from a fasted rat

\begin{tabular}{lll}
\hline & $\begin{array}{l}\text { No. of islets } \\
\text { per flask }\end{array}$ & $\begin{array}{l}\text { cpm }{ }^{14} \mathrm{CO}_{2} \\
\text { from } \\
\text { U- }{ }^{14} \mathrm{C}-g l u c o s e\end{array}$ \\
\hline Deoxyglucose & 16 & $584 \pm 76$ \\
Control & 16 & $507 \pm 94$ \\
Deoxyglucose (1) & 15 & $646 \pm 162$ \\
Control & 15 & $638 \pm 138$ \\
Deoxyglucose (2) & 14 & $392 \pm 41$ \\
Control & 14 & $497 \pm 11$ \\
\hline
\end{tabular}

cubated in 2-deoxy-D-glucose for $60 \mathrm{~min}$ before addition of the $\mathrm{U}_{-}{ }^{14} \mathrm{C}$-glucose (Table 3 ). This procedure also had no effect upon ${ }^{14} \mathrm{CO}_{2}$ production. D-man- noheptulose, in equimolar quantities, however, virtually abolished ${ }^{14} \mathrm{CO}_{2}$ production from $\mathrm{U}^{14} \mathrm{C}$ glucose (Table 4).

Table 4. The effect of mannoheptulose upon the production of ${ }^{14} \mathrm{CO}_{2}$ from $\mathrm{U}^{11} \mathrm{C}$-glucose by isolated islets

\begin{tabular}{llr}
\hline & $\begin{array}{l}\text { No. of islets } \\
\text { per flask }\end{array}$ & $\begin{array}{l}\text { cpm }{ }^{14} \mathrm{CO}_{2} \\
\text { from } \\
\text { U-14C-glucose }\end{array}$ \\
\hline Mannoheptulose & 15 & $179 \pm 100$ \\
Control & 15 & $1093 \pm 99$ \\
Mannoheptulose & 14 & $217 \pm 39$ \\
Control & 14 & $1138 \pm 136$ \\
\hline
\end{tabular}

\section{Discussion}

The failure of glucagon to reduce ${ }^{14} \mathrm{CO}_{2}$ production by islets incubated in radioactive glucose may be used as an argument against a glycogenolytic effect of the hormone in the B-cell if two prior assumptions are made. The first is that glucose-6-phosphate liberated within the B-cell mixes freely with that generated from glucose entering from outside. Although no direct information exists, it has been suggested (SAMors, MaRRI and MaRKS, 1966) that the existence of two pools of glucose-6-phosphate would explain certain phenomena. Further studies of islet metabolism are obviously necessary to resolve this point. The second assumption is that glucagon does not so stimulate glucose oxidation that the effect of dilution of the glucose-6-phosphate pool is masked by a rise in total $\mathrm{CO}_{2}$ production. Preliminary observations on the influence of glucagon on islet oxygen consumption (Hellerstrom and Turaner, 1967. Personal communication) and upon ${ }^{14} \mathrm{CO}_{2}$ production at various glucose concentrations (JARRETT and KaEN. Unpublished observations) suggest that this assumption is valid.

The more telling argument against a glycogenolytic effect of glucagon in the islet is provided by the failure of glucagon to reduce the radioactivity of previously labelled intra-islet glycogen. It is the more highly labelled outer tiers of the glycogen molecule which would be most vulnerable to glycogenolysis, and the absence of an effect of glucagon in this system is, in our opinion, good evidence against the hypothesis that glucagon promotes glycogenolysis.

HELLERSTROM (1967) found no effect of 2-deoxy-Dglucose upon basal or glucose stimulated oxygen consumption by the isolated mouse islet, results which are in accord with our own findings of its failure to influence ${ }^{14} \mathrm{CO}_{2}$ production from labelled glucose. It is evident that results obtained with other tissues (KIPNIS and CORI 1959) are not necessarily relevant to the metabolism of the islets. Devrim and ReCant (1966) suggested that 2-deoxy-D-glucose might inhibit the effect of glucagon by interfering with the further metabolism of glucose-6-phosphate, but in the light of Heilerstrour's and our own findings, this explana- 
tion seems unlikely. The effect of D-mannoheptulose upon ${ }^{14} \mathrm{CO}_{2}$ production is consistent with its effect upon oxygen consumption in the mouse islet (HELLERsTROM, 1967), and supports the suggestion made by Coore and RaNde (1964) that D-mannoheptulose prevents the phosphorylation of glucose by the B cell, as it has been shown to do in the liver.

Our observations shed no new light on the mechanism by which glucagon stimulates insulin release, but suggest that it is not effected by way of intra-B cell glycogenolysis.

\section{References}

Coore, H.G., and P.J. RANDLE: Regulation of insulin secretion studied with pieces of rabbit pancreas incubated in vitro. Biochem. J. 93, 66-78 (1964).

Devrim, S., and L. ReCANT: Effect of glucagon on insulin release in vitro. Lancet $1966 \mathrm{II}, 1227-1228$.

Grodsky, G.M., and L.L. Bennet: Effect of ghucose "pulse", glucagon, and the cations $\mathrm{Ca}^{++}, \mathrm{Mg}^{++}$, and $\mathrm{K}^{+}$ on insulin secretion in vitro. J. clin. Invest. 45, 1018 (1966).

Hetlerstrom, C.: Effects of carbohydrates on the oxygen consumption of isolated pancreatic islets of mice. Endoerinology 81, 105-112 (1967).

JARRET, R.J., and H. KEEN: Glucose metabolism of isolated mammalian islets of Langerhans. Lancet 1966 I, $633-635$.

Karam, J.H., S.G. Grasso, L.C. WegtenkKa, G.M. Grodsky, and P.H. ForshaM: Effect of selected hexoses, of epinephrine and of glucagon on insulin secretion in man. Diabetes 15, 571-578 (1966).

KEEN, H., R. Sells, and R.J. JaRReTr: A method for the study of the metabolism of isolated mammalian islets of Langerhans and some preliminary results. Diabetologia 1, 28-32 (1965).

KrPNIs, D.M., and C.F. CoRI: Studies of tissue permeability $V$. The penetration and phosphorylation of 2-deoxyglucose in the rat diaphragm. J. biol. Chem. 234, 171-177 (1959).

R-Candeia, J.L., R. R-Candela, D. Martin HerranDEZ, and T. CASTILIA-Cortazar: Insulin secretion in vitro. In "Perspectives in Biology", C.F. CoRI, V.G. Foglia, L.F. Lelore and S. OchoA, Editors., pp. 105-107. Amsterdam: Elsevier Publishing Co.1963.

Samols, E., G. Marri, and V. Marks: Promotion of insulin secretion by glucagon. Lancet $1965 \mathrm{I}, 415-416$.

- - - Interrelationship of glucagon, insulin and glucose. The insulinogenic effect of glucagon. Diabetes 15, $855-866(1966)$.

Sutherland, E.W., and T.W. RaLL: The relation of adenosine $3^{\prime}, 5^{\prime}$-phosphate and phosphorylase to the actions of catecholamines and other hormones. Pharmacol. Rev. 12, $265-276$ (1960).

TuRner, D.S., and N. McInTrRe: Stimulation by glucagon of insulin release from rabbit pancreas in vitro. Lancet $1966 \mathrm{I}, 351-352$.

TURTLE, J.R., and D.M. KIPNIs: An adrenergic receptor mechanism for the control of cyclic $3^{\prime \prime} 5^{\prime}$ Adenosine Monophosphate synthesis in tissues. Biochem. Biophys. Res. Comm. 28, 797-802 (1967).

UMBreit, W.W., R.H. BurRis, and J.F. StAUtFFr: "Manometric techniques", 4th Ed. Minneapolis: Burgess Publishing Co. 1964.

WOELLER, F.H.: Liquid scintillation counting of $\mathrm{C}^{14} \mathrm{O}_{2}$ with phenylethylamine. Analyt. Biochem. 2, 508-511 (1961).

R.J. JARRETT, M.D.

Department of Medicine

Guy's Hospital

London, S.E. 1, England 